\title{
Organic Greenhouse Container Herb Production in South Florida: Fertilizer and Potting Media ${ }^{1}$
}

\author{
D. D. Treadwell, Kati W. Migliaccio, Teresa Olczyk, Yun Qian, Y. Li, George J. Hochmuth, Robert \\ C. Hochmuth, Eric H. Simonne, Lance S. Osborne, and Richard K. Sprenkel2
}

\section{Background}

The organic industry has experienced steady growth in the number of farms, number of sales, and penetration of organic produce in the US market annually since 2002 (USDA ERS 2015). In 2019, sales of organic produce reached $\$ 18$ billion, 5\% more than the previous year (OTA 2019). Fresh produce, including herbs, continues to be the strongest category of sales in the organic market.

Field production of organic crops, including herbs, in south Florida is a challenging task due to the subtropical climate and high number of pest and disease pressures. Thus, greenhouse production of organic herbs may provide an alternate to field production. However, there is little published information on selecting media and fertilizers for organic herb production in greenhouses in this climate.

\section{Objectives}

Greenhouse trials were conducted during the 2005 and 2006 growing season at the UF/IFAS Tropical Research and Education Center (TREC) in Homestead, Florida. The objectives of the project were to 1) compare several commercially available organic fertilizers for organic greenhouse production of container herbs and 2) compare two commercially available potting media for organic greenhouse production of container herbs.

\section{Methods}

The three commercial certified organic fertilizers used in this project were Nature Safe (Griffin Industries, 8-5-5; Coldspring, KY), Fertrell (Fertrell Company, 4-2-4; Bainbridge, PA), and Perdue (Perdue Agri Recycle, 4-2-3; Seaford, Delaware). They were compared with a control treatment of no fertilizer application.

Two certified organic potting media were used. These were Fafard Organic formula (Conrad Farfard, Inc.; Agawam,

1. This document is ABE 373, one of a series of the Department of Agricultural and Biological Engineering, UF/IFAS Extension. Original publication date May 2007. Revised September 2020. Visit the EDIS website at http://edis.ifas.ufl.edu.

2. D. D. Treadwell, associate professor, organic and sustainable vegetable production, Horticultural Sciences Department; Kati W. Migliaccio, chair, Department of Agricultural and Biological Engineering; Teresa Olczyk, county Extension director, commercial agriculture/vegetables, UF/IFAS Extension Miami-Dade County; Yun Qian, former postdoctoral research associate, UF/IFAS Tropical Research and Education Center; Y. Li, professor, UF/IFAS TREC; George Hochmuth, professor (retired), Department of Soil and Water Sciences; Robert C. Hochmuth, regional specialized vegetable agent and assistant center director, UF/IFAS North Florida Research and Education Center; Eric H. Simonne, associate professor and northeast district Extension director; Lance S. Osborne, professor, UF/IFAS Mid-Florida REC; and Richard K. Sprenkel, Extension specialist (retired), UF/IFAS North Florida REC; UF/IFAS Extension, Gainesville, FL 32611.

The use of trade names in this publication is solely for the purpose of providing specific information. UF/IFAS does not guarantee or warranty the products named, and references to them in this publication does not signify our approval to the exclusion of other products of suitable composition. All chemicals should be used in accordance with directions on the manufacturer's label.

The Institute of Food and Agricultural Sciences (IFAS) is an Equal Opportunity Institution authorized to provide research, educational information and other services

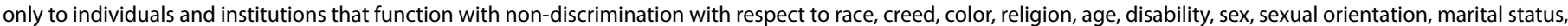

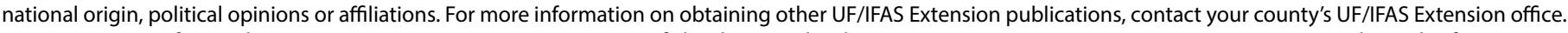
U.S. Department of Agriculture, UF/IFAS Extension Service, University of Florida, IFAS, Florida A \& M University Cooperative Extension Program, and Boards of County Commissioners Cooperating. Nick T. Place, dean for UF/IFAS Extension. 
MA) and Agro-Soils commercial potting medium (Agro Soils; Miami, FL).

The three organic fertilizers were mixed with the two potting media at specified rates (Fafard and Agro-Soils, Table 1). The different rates were due to the nutrient composition of each fertilizer. Table 1 also includes the cost per $50 \mathrm{lb}$ bag of each fertilizer.

The control treatment consisted of 0 grams of fertilizer per gallon of potting medium. Potting mixes were placed in 4 -inch diameter plastic pots. The four treatments (Nature Safe fertilizer, Fertrell fertilizer, Perdue fertilizer, and control [no fertilizer]) were replicated four times, and each replication consisted of six pots.

Pots were seeded with basil (Ocimum basilicum) (Figure 1) and dill (Anethum graveolens) (Figure 2). A light pinch of seeds (about $280 \mathrm{mg}$ seeds for basil and $170 \mathrm{mg}$ seeds for dill) was placed in each pot on the top of the potting mix and covered with $\sim 5 \mathrm{~mm}$ of potting mix.

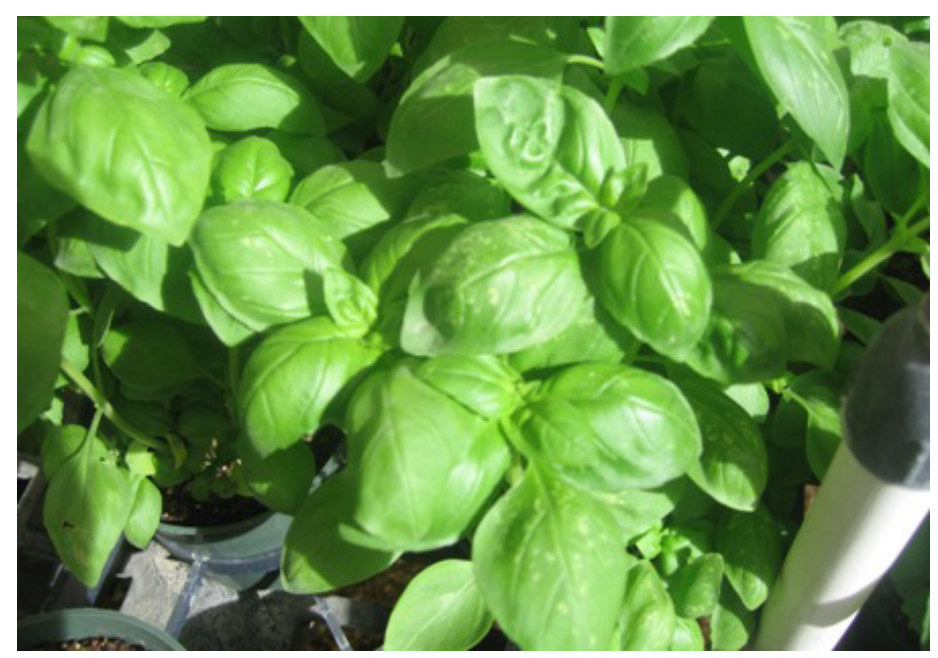

Figure 1. Basil showing its light green, silky broad leaves. Credits: Yun Qian, UF/IFAS

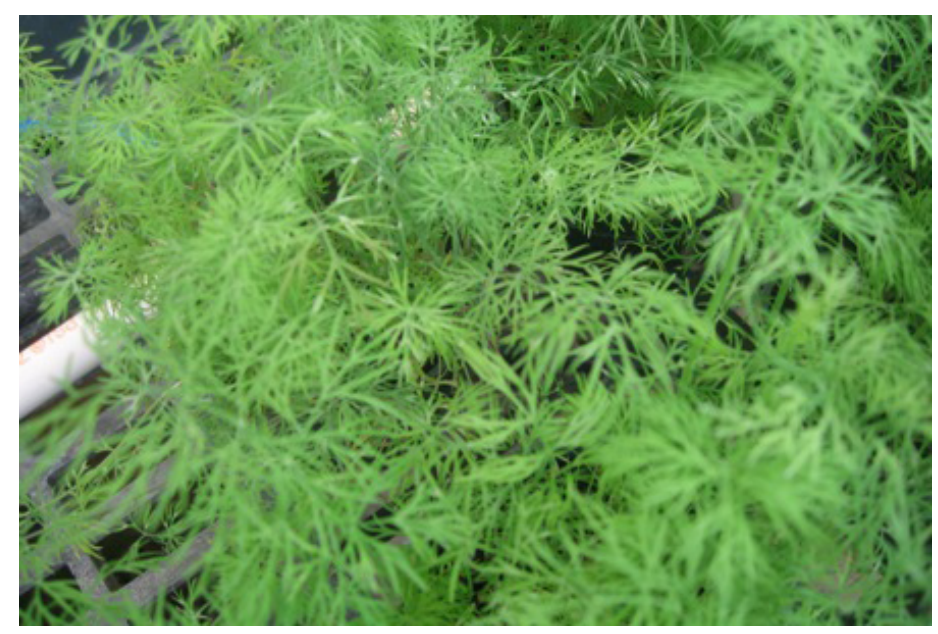

Figure 2. Dill showing its finely divided thread-like leaves. Credits: Yun Qian, UF/IFAS
Basil is available in many different types and has a pleasant aroma. Basil has green, tender broad leaves that may be used fresh or dried. Basil is well known for its culinary use; however, it is also a versatile landscape plant (Wetherbee 2001). Dill is a flavoring plant (i.e., dill pickles) with a strong aroma and fennel-like structure (Stephens 1998). Dill has also been used to sooth digestion and hiccups.

Pots were placed in a greenhouse and irrigated with timecontrolled overhead sprinklers. Plants were grown to obtain a marketable product to be sold as organic potted herbs. Irrigation was adjusted during the course of the experiment to ensure this goal.

Each of the two trials lasted approximately four weeks. The quality of plants at the end of four weeks was evaluated using several different criteria, including visual quality, fresh weight and dry weight of aboveground plant tissue, percent of total nitrogen (TN) and total carbon (TC) from plant tissue, nitrate $\left(\mathrm{NO}_{3}-\mathrm{N}\right)$ and potassium $\left(\mathrm{K}^{+}\right)$concentrations in plant sap, and $\mathrm{pH}$ and electric conductivity (EC) in leachate.

Leachate sampling for $\mathrm{pH}$ and $\mathrm{EC}$ was conducted as an indicator of nutrient loss from the potting mix by leachate.

Data were evaluated with analysis of variance and Duncan's multiple range test using PROC GLM program in SAS 9.1.2 to evaluate differences in mean values among fertilizer and potting media treatments. Statistics were completed for each trial separately.

\section{Results and Discussion}

Evaluation of results indicated that there were no significant differences between the two potting media for all measured parameters. Thus, the data were analyzed by fertilizer type only. Results are presented in Tables 2, 3, 4, and 5. The "a," "b," and "c" values in each table represent statistical results such that values with common letters are not significantly different and values with uncommon letters are significantly different.

The visual inspection, fresh weight, and dry weight measurements for basil and dill indicated that Perdue and Fertrell fertilizers provided the most visually pleasing and largest plants (Table 2 and Table 3).

Plant tissue nutrient results differed by herb (Table 4 and Table 5). Nutrient composition for basil was highly variable. Basil plants from the control fertilizer treatment had the greatest concentration of NO3-N for both trials. However, 
\%TN was the lowest in the control treatment for both trials. Percent TN was significantly greater in the Nature Safe basil treatment than other fertilizer treatments. The lack of correlation between NO3-N and \% TN was likely due to the different nature of the tests. For NO3-N, plant sap was measured from several leaves. Alternatively, \%TN was measured using dried biomass of a larger sample of the plant. Another possibility is the very nature of the nitrogen form. Percent TN includes both organic and inorganic forms of nitrogen, whereas NO3-N only considers the inorganic form of nitrogen.

Percent TC for basil treatments varied by trial. There were no significant differences in the first trial, and \%TC was significantly greater in Natural Safe and the control fertilizer treatments in the second trial.

For dill, NO3-N results were inconclusive with Fertrell having the greatest concentration in the first trial and Natural Safe and Perdue having the greatest concentrations in the second trial. Similarly, K+ results did not consistently identify one fertilizer as resulting in the greatest concentrations for dill. TN and TC percentages in dill also varied by trial; however, the Natural Safe fertilizer treatment was consistently high.

Hence, plant tissue and plant sap nutrient results did not clearly identify a fertilizer treatment that was significantly better than another.

Results from $\mathrm{pH}$ testing of leachate offered little additional information with minimal significant variation among treatments. Similarly, there were no significant differences among any treatments when evaluating leachate EC.

\section{Conclusions}

The two potting media (Fafard and Agro-Soils) did not result in significant differences in measured plant mass production, plant tissue nutrients, or leachate chemistry. However, some differences in plant production for basil and dill were identified among the different fertilizer treatments (Natural Safe, Perdue, Fertrell, and control). These differences were most notable for visual quality, fresh weight, and dry weight measurements. Evaluation of these parameters for basil and dill suggested that the two best fertilizers were Perdue and Fertrell. However, the differences in cost of each fertilizer and the study results suggest that Perdue is a more economic choice for organic herb production of basil and dill.
Results of these two trials for growing organic herbs in south Florida suggest that (1) there is no difference in using Fafard or Agro-Soils potting medium and (2) Perdue and Fertrell fertilizers resulted in greatest plant mass production. A full report of this project is available in HortTechnology as referenced below (Treadwell et al. 2011).

Clearly appropriate potting media and fertilizer formulations are commercially available for use in greenhouse production of basil and dill.

\section{References}

Organic Trade Association (OTA). 2019. Organic Market Overview. Accessed June 14, 2020. Available at: https://ota. $\mathrm{com} /$ resources/market-analysis

Stephens, J. M. 1998. Herbs in the Florida Garden. CIR570. Archived. Gainesville: University of Florida Institute of Food and Agricultural Sciences.

Treadwell, D. D., G. J. Hochmuth, R. C. Hochmuth, E. H. Simonne, S. A. Sargent, L. L. David, W. L. Laughlin, and A. Berry. 2011. "Organic Fertilization Programs for Greenhouse Fresh-Cut Basil and Spearmint in a Soilless Media Trough System." HortTechnology 21 (2): 162-169. https:// doi.org/10.21273/HORTTECH.21.2.162

USDA ERS. 2015. “Organic Market Overview.” Accessed June 14, 2020. Available at: https://www.ers.usda.gov/ topics/natural-resources-environment/organic-agriculture/ organic-market-overview/

Wetherbee, K. 2001. "A Bounty of Fresh Basil - Herb Gardening Tips.” Flower \& Garden Magazine. May 2001. 
Table 1. Potting mix rates of fertilizer and potting media.

\begin{tabular}{|l|l|c|c|}
\hline \multicolumn{1}{|c|}{ Fertilzer } & \multicolumn{1}{|c|}{ Composition } & $\begin{array}{c}\text { Cost per 50 lb bag } \\
\text { gallon of potting media }\end{array}$ \\
\hline Nature Safe & $\begin{array}{l}\text { Feather, meat, bone and blood meals, sulfate of potash, } \\
\text { yeast, sugars, carbohydrates, and humus }\end{array}$ & \multicolumn{1}{c}{$\begin{array}{c}\text { Com } \\
\text { galizer per }\end{array}$} \\
\hline Fertrell & $\begin{array}{l}\text { Aragonite, bone char, composted chicken manure, } \\
\text { sodium nitrate, feather meal, greensand, peanut meal, } \\
\text { sulfur, sulfate of potash }\end{array}$ & 80 \\
\hline Perdue & Poultry litter & $\$ 16.50$ \\
\hline
\end{tabular}

Table 2. Data collected for trial 1. Means with same letter are not significantly different by Duncan's multiple range test ( $p=0.05)$.

\begin{tabular}{|c|c|c|c|c|c|c|}
\hline Crop & Fertilizer & Visual & Fresh weight (g) & Dry weight (g) & $\begin{array}{c}\text { pH (standard } \\
\text { units) }\end{array}$ & $\mathrm{EC}(\mathrm{uS} / \mathrm{cm})$ \\
\hline Dill & Natural Safe & $2.03 b$ & $12.05 b$ & $2.08 \mathrm{~b}$ & 7.07ba & $1592 \mathrm{ba}$ \\
\hline Dill & Perdue & $4.25 a$ & $61.80 \mathrm{a}$ & $5.41 \mathrm{a}$ & $6.66 \mathrm{~b}$ & $1493 \mathrm{ba}$ \\
\hline Dill & Fertrell & $4.47 a$ & $59.31 a$ & $5.29 a$ & $6.72 \mathrm{a}$ & $3570 a$ \\
\hline Dill & Control & $1.00 \mathrm{c}$ & $5.53 b$ & $0.69 b$ & $7.29 a$ & $525 b$ \\
\hline Basil & Natural Safe & $2.75 b$ & $79.50 \mathrm{~b}$ & $4.78 b$ & $6.77 b$ & $1643 a$ \\
\hline Basil & Perdue & $4.56 a$ & $135.74 a$ & $9.03 a$ & $6.96 \mathrm{ba}$ & $450 \mathrm{a}$ \\
\hline Basil & Fertrell & $4.81 \mathrm{a}$ & 131.60a & $9.46 a$ & $6.90 \mathrm{ba}$ & $1772 a$ \\
\hline Basil & Control & $1.00 \mathrm{c}$ & $12.59 c$ & $1.64 c$ & $7.37 a$ & $392 a$ \\
\hline
\end{tabular}

Table 3. Data collected for trial 2. Means with same letter are not significantly different by Duncan's multiple range test $(p=0.05)$.

\begin{tabular}{|c|c|c|c|c|c|c|}
\hline Crop & Fertilizer & Visual & Fresh weight (g) & Dry weight (g) & $\begin{array}{l}\text { pH (standard } \\
\text { units) }\end{array}$ & $\mathrm{EC}(\mathrm{uS} / \mathrm{cm})$ \\
\hline Dill & Natural Safe & $1.19 b$ & $5.28 \mathrm{~b}$ & $0.13 b$ & $7.13 \mathrm{ba}$ & $432 a$ \\
\hline Dill & Perdue & $2.25 a$ & $14.11 \mathrm{a}$ & $0.58 a$ & $7.05 b$ & $472 a$ \\
\hline Dill & Fertrell & $2.38 \mathrm{a}$ & $13.66 a$ & $0.56 a$ & $7.14 \mathrm{ba}$ & $460 \mathrm{a}$ \\
\hline Dill & Control & $1.00 \mathrm{~b}$ & $4.31 b$ & $0.19 b$ & $7.21 a$ & $414 a$ \\
\hline Basil & Natural Safe & $3.19 b$ & $51.78 b$ & $2.84 b$ & $7.05 a$ & $357 a$ \\
\hline Basil & Perdue & $4.25 a$ & $89.88 a$ & $4.84 a$ & $7.07 a$ & $382 a$ \\
\hline Basil & Fertrell & $4.31 a$ & $83.49 a$ & $4.79 a$ & $7.18 a$ & $373 a$ \\
\hline Basil & Control & $1.00 c$ & $11.74 \mathrm{C}$ & $0.66 c$ & $7.20 a$ & $396 a$ \\
\hline
\end{tabular}

Table 4. Nutrient data collected for trial 1 . Means with same letter are not significantly different by Duncan's multiple range test $(p=0.05)$.

\begin{tabular}{|c|c|c|c|c|c|}
\hline Crop & Fertilizer & $\mathrm{NO}_{3}-\mathrm{N}(\mathrm{mg} / \mathrm{L})$ & $K(\mathrm{mg} / \mathrm{L})$ & $\% \mathrm{TN}$ & $\%$ TC \\
\hline Dill & Natural Safe & $1095 b$ & $1197 \mathrm{cb}$ & $4.0 \mathrm{a}$ & $35.3 a$ \\
\hline Dill & Perdue & $682 b$ & $2167 a$ & $2.7 \mathrm{~b}$ & $34.6 \mathrm{ba}$ \\
\hline Dill & Fertrell & $5047 a$ & $1643 b$ & $4.2 \mathrm{a}$ & $34.0 \mathrm{~b}$ \\
\hline Dill & Control & $832 b$ & $843 c$ & $1.0 \mathrm{c}$ & $34.0 \mathrm{~b}$ \\
\hline Basil & Natural Safe & $1162 b$ & $682 a$ & $4.0 \mathrm{a}$ & $36.5 a$ \\
\hline Basil & Perdue & $402 b$ & $805 a$ & $2.5 \mathrm{c}$ & $37.1 \mathrm{a}$ \\
\hline Basil & Fertrell & $918 b$ & $588 a$ & $3.1 b$ & $37.1 \mathrm{a}$ \\
\hline Basil & Control & $4645 a$ & $345 a$ & $1.0 \mathrm{~d}$ & $37.1 \mathrm{a}$ \\
\hline
\end{tabular}


Table 5. Nutrient data collected with statistical indicators for trial 2.

\begin{tabular}{|c|c|c|c|c|c|}
\hline Crop & Fertilizer & $\mathrm{NO}_{3}-\mathrm{N}(\mathrm{mg} / \mathrm{L})$ & $K(\mathrm{mg} / \mathrm{L})$ & $\% \mathrm{TN}$ & $\%$ TC \\
\hline Dill & Natural Safe & $653 \mathrm{ba}$ & $1547 a$ & $3.2 \mathrm{a}$ & $33.4 a$ \\
\hline Dill & Perdue & $762 a$ & $1577 a$ & $2.8 \mathrm{ba}$ & $32.3 b$ \\
\hline Dill & Fertrell & $345 b c$ & $1007 a$ & $2.5 b$ & $33.2 \mathrm{a}$ \\
\hline Dill & Control & $313 c$ & $1295 a$ & $1.3 c$ & $33.6 a$ \\
\hline Basil & Natural Safe & $413 a$ & $235 b$ & $3.0 \mathrm{a}$ & $35.7 \mathrm{ba}$ \\
\hline Basil & Perdue & $405 a$ & $493 a$ & $2.1 b$ & $34.8 \mathrm{c}$ \\
\hline Basil & Fertrell & $248 a$ & $410 a$ & $2.0 \mathrm{~b}$ & $35.3 b$ \\
\hline Basil & Control & $452 a$ & $457 a$ & $1.2 \mathrm{c}$ & $36.1 a$ \\
\hline
\end{tabular}

